\title{
Newborn Hearing Screening Results of Duzce Province in the Western Black Sea Region
}

\author{
Ahmet KODER 國, Abdullah BELADA 國 ${ }^{2}$
}

\begin{abstract}
Aim: We aimed to evaluate the results of newborn hearing screening (NHS) conducted at Düzce Atatürk State Hospital, and review the results with the relevant literature.

Material and Methods: The hearing screening results of 20071 newborns whose hearing screening was conducted at Düzce Atatürk State hospital between January 2011 and December 2018 were evaluated retrospectively in this study. Refugees were not included in the study. Newborns without risk factors who came to the first test were evaluated with transient evoked otoacoustic emissions (TEOAE). If they failed from the first screening test were evaluated again 15 days later with TEOAE. Newborns who failed the second screening test were evaluated a third time with ABR. Newborns with risk factors were first evaluated with auditory brainstem response (ABR).The risky newborns who failed the first screening test were evaluated second time with ABR.

Results: Hearing loss was present in $62(0.30 \%)$ of the 20071 newborns and was unilateral in $35(0.17 \%)$ and bilateral in $27(0.13 \%)$ subjects.

Conclusion: For the rehabilitation of babies with hearing loss, their treatment should be started as early as possible. Newborn hearing screening tests are a screening program that has been successfully applied in our country for many years and enables the detection of babies with hearing loss. With this screening program, babies with hearing loss can be detected at an early stage and their treatment and rehabilitation can be provided. The results of our study are consistent with other hearing screening results from our country.
\end{abstract}

Keywords: Newborn; hearing loss; otoacustic emission; auditory brainstem response.

\section{$\ddot{\mathbf{O Z Z}}$}

\section{Batı Karadeniz Bölgesi Düzce İli'ndeki Yenidoğan İşitme Taraması Sonuçları}

Amaç: Düzce Atatürk Devlet Hastanesi'nde yapılan yenidoğan işitme tarama sonuçlarını değerlendirmek ve güncel literatür eşliğinde tartışmak amaçlanmıştır.

Gereç ve Yöntemler: Çalışmamızda Ocak 2011- Aralık 2018 tarihleri arasında Düzce Atatürk Devlet Hastanesi'nde işitme taraması yapılan 20071 yenidoğanın işitme tarama sonuçları retrospektif olarak değerlendirildi. Mülteciler çalışmaya dahil edilmedi. İlk teste gelen ve risk faktörü olmayan yenidoğanlar uyarılmış transient otoakustik emisyonlar (TEOAE) ile değerlendirildi. Birinci taramadan kalan yenidoğanlar 15 gün sonra tekrar TEOAE ile değerlendirildi. İkinci tarama testinden kalanlar üçüncü kez işitsel beyin sapı yanıt ile (ABR) değerlendirildi. Risk faktörü olan yenidoğanlar ilk olarak ABR ile değerlendirildi. İlk testten kalanlar ikinci kez yine ABR ile değerlendirildi.

Bulgular: Toplam 20071 yenidoğanın $62(\% 0,30)$ tanesinde işitme kaybı mevcuttu. $35(\% 0,17)$ tanesinde tek taraflı $27(\% 0,13)$ ünde ise çift taraflı idi.

Sonuç: İşitme kayıplı bebeklerin rehabilitasyonu için tedavilerinin mümkün olduğunca erken dönemde başlanması gerekmektedir. Yenidoğan işitme tarama testleri uzun yıllardır ülkemizde başarıyla uygulanan ve işitme kayıplı bebeklerin tespit edilmesini sağlayan bir tarama programıdır. Bu tarama programı ile işitme kayıplı bebekler erken dönemde tespit edilerek tedavi ve rehabilitasyonları sağlanabilmektedir. Çalışmamızda ülkemizde yapılan diğer işitme tarama sonuçlarıyla uyumlu olarak bulunmuştur.

Anahtar Kelimeler: Yenidoğan; işitme kaybı; otoakustik emisyon; işitsel beyinsapı yanıtı

1 Department of Otorhinolaryngoloy, Duzce Ataturk State Hospital Duzce, Turkey

2 Department of Otorhinolaryngoloy, Duzce University Faculty of Medicine, Duzce, Turkey

Sorumlu Yazar / Corresponding Author: Ahmet Köder, e-mail: ahmetkoder@yahoo.com

Geliş Tarihi / Received: 04.03.2021, Kabul Tarihi / Accepted: 26.05.2021

This article has been presented previously in TKBBV 5. Spring online meeting orally at 12-14 November 2020. 


\section{INTRODUCTION}

NHS is very important for the early diagnosis, treatment and rehabilitation of hearing loss. Hearing loss in newborns is the most common congenital defect with an incidence of $1-3$ per 1000 live births $(1,2)$. The aim in our country is to perform hearing screening to detect hearing loss in all newborns, either before discharge if they were born in a hospital or during the first follow-up if they were born outside. The American Academy of Pediatrics recommends screening all newborn infants within the first month after birth. Hearing loss should be confirmed within three months if present and the necessary medical intervention should be performed within six months (3). The ABR (Auditory Brainstem Response) and EOAE (Evoked Otoacustic Emissions) tests are used for newborn hearing screening.

NHS of 20071 newborns whose hearing screening was conducted at Düzce Atatürk State Hospital between January 2011 and December 2018 were reviewed with the relevant literature in this study.

\section{MATERIAL AND METHODS}

\section{Ethics approval}

Our study protocol was approved by the ethics committee of Duzce University (Decision date: 04/01/2021, IRB number: 2020-273).

The pre-discharge hearing screening results of the newborns who were born at Düzce Atatürk State Hospital and the hearing screening results of the newborns referred to our hospital from the surrounding areas between January 2011 and December 2018 were evaluated retrospectively in our study. Refugees were not included in the study. Newborns who had their first and/or second screening test but did not come to follow-up were excluded. The study contains the recorded hearing screening data of 20071 newborns in total.

Hearing screenings were performed every weekday in an isolated room at Düzce Atatürk State Hospital by three experienced audiometrists who had previously received special training. The Autodynamics ILO288 Serial No: EP4/05/0780/11 device was used for OAE and the Maico MB11 Series No:7867048 model device for ABR tests.

Newborns without risk factors who came to the first test were evaluated with transient evoked otoacoustic emissions (TEOAE). If they failed from the first screening test they were evaluated again 15 days later with TEOAE. Newborns who failed the second screening test were evaluated a third time with ABR. Newborns with risk factors were evaluated with auditory brainstem response $(\mathrm{ABR})$ as the first test. The risky newborns who failed the first screening test were evaluated a second time with ABR. The measurements were performed preferably while the infant was asleep but also while awake with still and calm newborns. We usually waited for the infants to fall asleep after being breastfed and for the time when they were most calm. The tests were performed in a quiet room specially reserved for testing. Appropriate pediatric probes were placed in the infant's ears. "Passed" was accepted as the criterion for an automatic pass. The infants where a "passed" result was obtained in both ears automatically passed the test.

Newborns where a "passed" result was not obtained from both ears were called for follow-up 15 days later to repeat the test. During the second test, newborns whose both ears passed successfully were accepted as having passed the test. Newborns who could not pass the second screening test were examined by an otorhinolaryngologist. The patency of the outer ear canal was evaluated together with the eardrum. If otitis media or any other condition that might have resulted in test failure was present, the patients were prescribed the necessary treatment and called for follow-up 15 days later. Newborns who could not pass the test for the third time were referred to reference diagnostic centers designated by the Ministry of Health Figure 1. The screening results were registered in the newborn hearing screening follow-up form. The family was given a document that contained the screening result.

\section{RESULTS}

The hearing screening results of 20071 newborns whose hearing screening was conducted between January 2011 and December 2018 were evaluated. The first hearing screening was passed by $17445(86.9 \%)$ newborns. Of the remaining 2626 newborns, $2564(12.7 \%)$ passed the second or third hearing screening test. The number of newborns who could not pass the three screening tests and were referred to an advanced diagnostic center was $62(0.30 \%)$. The suspicion of hearing loss was bilateral in $27(0.13 \%)$ newborns, only in the right ear in $22(0.10 \%)$ newborns and in the left ear in $13(0.06 \%)$ newborns.

Table 1. Newborn hearing screning results

\begin{tabular}{|l|c|c|c|c|}
\hline & $\begin{array}{l}\text { Screning } \\
\text { New Born }\end{array}$ & $\begin{array}{l}\text { 1. } \\
\text { Screening }\end{array}$ & $\begin{array}{l}\text { 2. or 3. } \\
\text { Screening }\end{array}$ & $\begin{array}{l}\text { Referred to a } \\
\text { higher } \\
\text { healthcare } \\
\text { center or } \\
\text { Hearing loss } \\
\text { diagnosed }\end{array}$ \\
\hline $\begin{array}{l}\text { Zekai Tahir } \\
\text { Burak } \\
\text { Maternity } \\
\text { hospital }\end{array}$ & 142128 & 115438 & 26305 & $385(0.27 \%)$ \\
\hline $\begin{array}{l}\text { Van } \\
\text { Ipekyolu } \\
\begin{array}{l}\text { Maternity } \\
\text { Hospital }\end{array}\end{array}$ & 52228 & 50459 & 1607 & $272(0.52 \%)$ \\
\hline $\begin{array}{l}\text { Düzce } \\
\text { Atatürk } \\
\text { State } \\
\text { Hospital }\end{array}$ & 20071 & 17445 & 2564 & $62(0.30 \%)$ \\
\hline $\begin{array}{l}\text { Denizli State } \\
\text { Hospital }\end{array}$ & 19464 & 14846 & 3444 & $18(0.09 \%)$ \\
\hline $\begin{array}{l}\text { Bolu İzzet } \\
\text { Baysal } \\
\text { Maternity } \\
\text { Hospital }\end{array}$ & 12232 & 10036 & 2118 & $22(0.16 \%)$ \\
\hline $\begin{array}{l}\text { Zeynep } \\
\text { Kamil } \\
\text { Maternity } \\
\text { Hospital }\end{array}$ & 11053 & 8490 & 2546 & $17(0.15 \%)$ \\
\hline $\begin{array}{l}\text { İmir } \\
\text { Atatürk } \\
\text { Research } \\
\text { Hospital }\end{array}$ & 7918 & 7435 & 461 & $22(0.27 \%)$ \\
\hline $\begin{array}{l}\text { Hacettepe } \\
\text { University }\end{array}$ & 5485 & 5026 & 307 & $11(0.20 \%)$ \\
\hline $\begin{array}{l}\text { Karaman } \\
\text { State } \\
\text { Hospital }\end{array}$ & 8003 & 5591 & 2374 & $26(0.32 \%)$ \\
\hline $\begin{array}{l}\text { Adana City } \\
\text { Training } \\
\text { and } \\
\text { Research } \\
\text { Hospital }\end{array}$ & 2022 & 1502 & 486 & $34(1.7 \%)$ \\
\hline
\end{tabular}






Figure1. Newborn hearing screening programme DISCUSSION

Hearing is vital for speech development. Hearing loss has an adverse influence on children's speech and language development, psychological and social development. Children born with hearing loss and who were diagnosed at their early ages, and were interfered with appropriate and correct treatment would acquire better speech, cognitive and social skills. Therefore, neonates are required to be tested against hearing impairment for early diagnosis. Hearing screening tests were previously performed only at university hospitals but then became compulsory at the order of the Ministry of Health in 2008 and the current aim is to screen all newborns born in our country. The aim of the program is to treat and rehabilitate newborns found to have hearing loss at early stage. Hearing loss is the most common congenital defect in newborns with an incidence of 1-3 per 1000 live births $(1,2)$. It was reported that an auricular deformity was seen in every 6,000 births. Genetic causes, intrauterine infections (rubella, syphilis), ischemic damages, ototoxic medications (talidomid, isotretionin) and environmental factors could cause ear deformities for example aural atresia can be experienced 1 in every 20,000 live birth. About $10-15 \%$ of subjects exhibit internal ear anomalies (3). Treatment and rehabilitation is possible if these newborns can be detected at an early stage. The American Academy of Pediatrics recommends screening within the first month for all newborn infants. If hearing loss is found, it should be confirmed within the first three months and the necessary medical intervention provided within the first six months (4). The aim in our country is to screen all newborns within one month after birth Auditory Brainstem Response (ABR) and Evoked Otoacoustic Emissions (EOAE) are used in newborn hearing screening (5). The outer hair cells in the cochlea are stimulated and their signals recorded by probes placed in the outer ear canal with the otoacoustic emission test. The presence of this response in both ears indicates normal function of the outer hair cells with no hearing loss of more than $40 \mathrm{~dB}$ (6-8). Otoacoustic emissions are not invasive; therefore they are convenient and completed in a brief time because it does not require electrodes. However, if cerumen or debris exists in external auditory canal or if there is effusion in tympanum, misleading results could arise and this test is not capable of detecting retro-cochlear pathologies. ABR is based on the principle of evaluating the electrical response of the brainstem auditory pathway and hearing nerve to a click stimulus (9).

Yucel et.al found quite high in their study Syrian refugees NHS results than Turkish population. Refugee patient population had many risks in terms of prenatal, perinatal and postnatal periods. They are facing with many problems on journey from homel and to new home. This situation becomes more difficult for pregnant women (10). Such reasons as the fact that refugees experience food and shelter problems due to war and compulsory immigration conditions, safety concerns and economic problems make the pregnancy period more difficult for pregnant women and refugee mothers are subject to malnutrition and stress throughout pregnancy (11). In our study refugees weren't include the study. Newborn hearing screening at the Düzce Atatürk State Hospital's Otorhinolaryngology Department has been conducted since 2005 by audiometrists who have received training on the subject. We evaluated the hearing screening results of 20071 newborns in this study. A pass result was obtained by 17445 of these newborns during the first test. Of the remaining 2626 newborns, 2564 passed the second or third hearing screening test. The number of newborns who could not pass any of the three screening tests and were then referred to a higher center was $62(0.30 \%)$. The hearing loss detected was bilateral in $27(0.13 \%)$ newborns, only in the right ear of $22(0.10 \%)$ newborns and only in the left ear of $13(0.06 \%)$ newborns. In Kilicaslan et. al. found in their study that NHS results higher than other studies (12). This high rate in comparison with other studies in the literature can be subject to various risk factors such as inclusion of neonates in intensive care department; higher kin marriage rate with respect to other regions; and babies monitored at our hospital had greater risk factors in terms of early delivery or birth defects in comparison with other health institutions. The most important reasons; family history, craniofacial anomalies, intrauterine TORCH infection, severe hyperbiluribinemia, treatment in intensive care unit, prolonged mechanical ventilation and hearing loss related to syndromes (11).Table 1 presents the results of the hearing screening tests conducted in Turkey (12-18). Bilateral hearing loss was found at a rate of $0.13 \%$ and unilateral hearing loss at a rate of $0.17 \%$ in our study and these results were consistent with other studies. 


\section{CONCLUSION}

Hearing loss is one of the most important factors affecting speech development. It is very difficult to ensure speech development if hearing loss is not detected in the prelingual period. Early diagnosis and treatment are therefore essential. Newborn hearing screening should be provided for all newborns.

This is the first study to provide the results of hearing screening conducted in Düzce Province in the Western Black Sea Region. It contains significant information related to these geographic areas.

All newborns born in the hospital should undergo hearing screening before discharge. Those who are born at home should be tested within the first month and the diagnosis should be made within the first three months so that the necessary treatment and rehabilitation processes can be started within the first sixth months. It is possible to ensure language and speech development in children with hearing loss in this way.Conflict of Interest: All authors report that they have no conflict of interests.

Financial Disclosure: All authors have no financial relationships involved for this study.

Acknowledgements: None declared by the authors.

Authors's Contributions: Idea/Concept: A.K.; Design: A.K.; Data Collection and/or Processing: A.K, A.B.; Analysis and/or Interpretation: A.K, A.B. ; Literature Review: A.K.; Writing the Article: A.K, A.B.; Critical Review: A.B.

\section{REFERENCES}

1. Thompson DC, McPhillips H, Davis RL, Lieu TL, Homer CJ, Helfand M. Universal newborn hearing screening. Summary of evidence. JAMA. 2001; 286(16): 2000-10.

2. Oudesluys-Murphy AM, Van Straaten HL, Bholasingh R, Van Zanten GA. Neonatal hearing screening. Eur J Pediatr. 1996; 155(6): 429-35.

3. Teufert KB, De La Cruz A. Advances in congenital aural atresia surgery: Effects on outcome. Otolaryngol Head Neck Surg. 2004; 131(3): 263-70.

4. Erenberg A, Lemons J, Sia C, Trunkel D, Ziring P. Newborn and infant hearing loss: detection and intervention. American Academy of Pediatrics. Task force on newborn and infant hearing. Pediatrics. 1999; 103(2):527-30.

5. Thornton AR, Kimm L, Kennedy CR. Methodological factors involved in neonatal screening using transientevoked otoacustic emissions and automated auditory brainstem response testing. Hearing Research. 2003; 182: 65-76.

6. Kemp DT, Ryan S, Bray P. A guide to effective use of otoacoustic emissions. Ear Hear. 1990; 11(2): 93105.

7. Kenna MA. Neonatal hearing screening. Pediatr Clin N Am. 2003; 50(2): 301-13.

8. Paludetti G, Ottaviani F, Fetoni AR, Zuppa AA, Tortorolo G. Transient evoked otoacustic emissions in new-borns: normative data. Int $J$ Pediatr Otorhinolaryngol. 1999; 47(3): 235-41.

9. World Health Organization. Newborn and Infant Hearing Screening: current issues and guiding principles for action. Geneva. WHO Press, 2010:14.

10. Yucel A, Alataş N, Yucel H, Gulluev M, Ozsoz E, Uğur C. Newborn hearing screening results of refugees living in our city and the factors affecting the results, Int J Pediatr Otorhinolaryngol. 2019; 123: 187-90. https://doi.org/10. 016/j.ijporl.2019.05.019.

11. C1krıkcı S, Deniz H, Gulşen S. Comparison of hearing screening results of Syrian refugees and Turkish newborns. Int J Pediatr Otorhinolaryngol. 2020; 135: 110095. https://doi.org/ 10.1016/j.ijporl.2020.110095.

12. Kılıçaslan S, Kılıçaslan R, Uluyol S, Gür M H. Van bölgesi yenidoğan işitme tarama sonuçları ve literatür taramas1. KBB ve BBC Dergisi. 2017; 25 (3): 25-30 https://doi.org/10.24179/kbbbbc.2016-54397.

13. Genç GA, Başar F, Kayıkçı ME, Türkyılmaz D, Fırat Z, Duran Ö. Hacettepe Üniversitesi yenidoğan işitme taraması bulguları. Çocuk Sağlığı ve Hastalıkları Dergisi. 2005; 48: 119-24.

14. Çelik İ, Canpolat FE, Demirel G, Eras Z, Sungur VG, Karaer B, et al. Zekai Tahir Burak Women's Health Education and Research Hospital newborn hearing screening results and assessment of the patients. Turk Pediatri Ars. 2014; 49(2): 138-41.

15. Kucur C, Kınış V, Özdem Ş, Kucur SK, Newborn hearing screening results at Zeynep Kamil Women and Children Diseases Education and Research Hospital. Kulak Burun Bogaz Ihtis Derg. 2012; 22(1): 38-42.

16. Baydar Y, Pınar E, Katılmış H, Soy FK, Çamlı C. The results of newborn hearing screening test and its significance Tepecik Eğit Hast Derg. 2012; 22 (2): 93-6.

17. Övet G, Balcı YI, Canural R, Çövüt İE, Bekçi Ş, Erbil $\mathrm{N}$, ve ark. Yenidoğan işitme taraması sonuçlarımız. Adnan Menderes Üniversitesi Tıp Fakültesi Dergisi. 2010; 11(1): 27- 9 .

18. Yılmaz B, Küçükbayrak B. Results of newborn hearing screening. Abant Medical Journal. 2013; 2(3): 204-7. 